\title{
ANALISIS PERTIMBANGAN HAKIM DALAM PUTUSAN No.0253/Pdt.P/2016/PA.Pbg TENTANG DISPENSASI PERNIKAHAN
}

\author{
Ali Mutakin*(a,1) dan Lusi Marwati ${ }^{*}(b, 1)$ \\ Sekolah Tinggi Agama Islam Nurul Iman \\ 1 ni5316627@gmail.com*; 2 lusimarwati272@gmail.com*
}

\begin{abstract}
Abstact Marriage dispensation is the granting of the right by the Religious Courts to a person to marry even though they

Received:

03-12-2021

Revised:

09-12-2021

Published:

13-01-2022 have not reached the minimum age for marriage, if the situation "requires" and there is no other option. In an effort to grant a marriage dispensation, the Religious Courts are required to provide considerations that prioritize the concept of maslahah, namely considerations of goodness and rejecting harm (madharat) in society. This article aims to analyze the decision no.0253/Pdt.P/2016/PA.Pbg regarding marriage dispensation. The type of research used is a normative legal research model (doctrinal). The primary data source used is a copy of the decision of the religious court no. 0253/Pdt.P/2016/PA.Pbg, while the secondary data are books, journal articles related to the discussion theme. The data analysis technique used descriptive analysis, where the data obtained were described and then analyzed. The findings of this article are some of the considerations that become the judge's reference in determining decision no. 0253/Pdt.P/2016/PA.Pbg are 1) based on Law Number 16 of 2019 concerning amendments to Law Number 1 of 1974 concerning Marriage. 2) based on written evidence and statements from the two witnesses. 3) based on the true benefit.
\end{abstract}

Keywords: Dispensation, Benefit, Judge's Consideration

Abstrak Dispensasi pernikahan merupakan pemberian hak oleh Pengadilan Agama kepada seseorang untuk menikah meski belum mencapai batas minimum usia pernikahan, jika keadaan "menghendaki" dan tidak ada pilhan lain. 
Diterima:

03-12-2021

Direvisi:

09-12-2021

Dipublikasi:

13-01-2022

Dalam upaya pemberian dispensasi pernikahan, Pengadilan Agama dituntut untuk memberikan pertimbangan yang mengedepankan konsep maslahahat, yaitu pertimbangan kebaikan dan menolak kerusakan (madharat) dalam masyarakat. Artikel ini bertujuan untuk menganalisis ketetapan putusan no.0253/Pdt.P/2016/PA.Pbg tentang dispensasi pernikahan. Tipe penelitian yang digunakan adalah model penelitian hukum normatif (doctrinal). Sumber data primer yang digunakan adalah salinan putusan pengadilan agama no. 0253/Pdt.P/2016/PA.Pbg, sedangkan data sekunder berupa buku, artikel jurnal yang berkaitan dengan tema pembahasan. Teknik analisis data menggunakan deskriptif analisis, dimana data-data yang diperoleh dideskripsikan kemudian dianalisis. Temuan artikel ini adalah beberapa pertimbangan yang menjadi acuan hakim dalam menetapkan putusan no. 0253/Pdt.P/2016/PA.Pbg adalah 1) berdasarkan pada Undang-undang Nomor 16 Tahun 2019 tentang perubahan Undang-undang Nomor 1 Tahun 1974 Tentang Perkawinan. 2) berdasarkan bukti-bukti tertulis dan keterangan dari kedua saksi. 3) berdasarkan kemaslahatan yang hakiki.

\section{Katakunci : Dispensasi, Kemaslahatan, Pertimbangan Hakim}

\section{PENDAHULUAN}

Perkawinan memiliki arti penting dalam kehidupan manusia dimana perkawinan menimbulkan akibat-akibat hukum, bukan hanya pada suami-istri yang bersangkutan, melainkan juga kepada anak-anaknya, orang tua, keluarga dan masyarakat sekitar. Perkawinan merupakan suatu lembaga suci untuk membentuk keluarga bahagia dan kekal, sesuai dengan Undang-undang No. 1 tahun 1974 tentang perkawinan yang menyebutkan bahwa pernikahan ialah ikatan lahir batin suami dan istri untuk membentuk 
keluarga bahagia berdasarkan Ketuhanan Yang Maha Esa. ${ }^{1}$ Dalam Al-Qur'an pun, pernikahan disebut sebagai mitsaqan ghalidza atau "perjanjian agung"2. Hal ini menunjukan bahwa pernikahan dalam Islam bukan sembarang perjanjian, tapi "Perjanjian Agung", di mana dalam bahasa Al-Qur'an disejajarkan dengan mitsaqan ghalidza (Perjanjian Agung) antara Allah dengan para Rasul berpredikat Ulul Azmi, yaitu Nabi Nuh, Ibrahim, Musa, dan Isa ${ }^{3}$ dan mitsaqan ghalidza antara Allah dengan Bani Israil, di mana dalam AlQur'an Allah menceritakan bahwa dalam melakukan perjanjian tersebut sampai-sampai Allah angkat Gunung Thursina di atas kepala Bani Israel. ${ }^{4}$

Hakikat pernikahan adalah menyatukan dua manusia yaitu laki-laki dan perempuan dalam satu ikatan legal untuk membina rumah tangga. Pernikahan merupakan komitmen yang didalamnya terdapat ikatan emosional antara dua orang untuk saling berbagi tanggung jawab psikis maupun biologis. Melaksanakan pernikahan menjadi keinginan bagi setiap orang yang cukup umur dan dewasa, serta memiliki kesiapan untuk membentuk keluarga bahagia sesuai impiannya. Selain itu menikah merupakan sunnatullah, sunnah para rasul dan merupakan sunah yang sangat dianjurkan oleh Rasulullah Saw.

Tujuan pernikahan secara umum adalah untuk membentuk keluarga yang bahagia, harmonis, tentram dan sakinah. Untuk mewujudkannya agama Islam memperintahkan umat muslim untuk melakukan pernikahan sebagai jalan terbaik untuk penyaluran hawa

1 Lihat pasal 1 Undang-undang Nomor 1 Tahun 1974 tentang Perkawinan.

${ }^{2}$ Lihat dalam QS. Al-Nisa: 21.

${ }^{3}$ Lihat QS. Al-Ahzab: 7.

${ }^{4}$ Lihat QS. Al-Nisa: 154. 
nafsu dan wujud kerjasama antara laki-laki dan perempuan. ${ }^{5}$ Sebagaimana dalam firman Allah, seperti yang tercantum dalam Al-Qur'an surat An-Nur ayat 32:

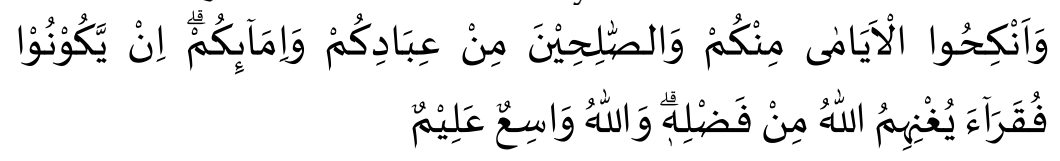

Dan nikahkanlah orang-orang yang masih membujang di antara kamu, dan juga orang-orang yang layak (menikah) dari hamba-hamba sahayamu yang laki-laki dan perempuan. Jika mereka miskin, Allah akan memberi kemampuan kepada mereka dengan karunia-Nya. Dan Allah Mahaluas (pemberian-Nya), Maha Mengetahui.

Ayat tersebut menjelaskan bahwa perkawinan sangat dianjurkan oleh Allah dan Nabi, kepada laki-laki dan perempuan yang masih membujang6, untuk membentuk dan membina keluarga bahagia.7 Bahagia adalah dambaan setiap keluarga, karena hal tersebut menjadi harapan suami istri dalam tujuannya melangsungkan sebuah pernikahan agar nantinya tercipta keluarga yang diliputi rasa tenang (sakinah), tumbuh perasaan cinta yang penuh dengan kasih sayang (mawadah wa rahmah). ${ }^{8}$ Seperti firman Allah dalam QS. Ar-Rum (30): 28

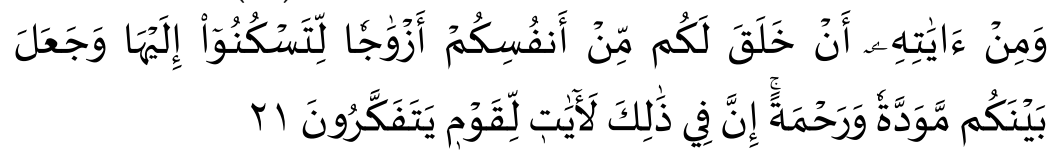

5 Andi Hakim Nastution, Membina keluarga bahagia Jakarta: PT Pustaka Antara ,1996), cet.4. hlm 28,

6 Amir Syarifudin, Hukum Perkawinan Islam diIndonesia, (Jakarta: Kencana, 2006).

7 Ridwan Syahrani,Seluk Beluk dan Asas-asas Hukum Perdata, (Bandung:Pustaka Setia, 2015), hlm.152.

8 Syekh Mahmud Al Mashri, Perkawinan Idaman, Jakarta: Qisthi Press, 2015), cet. 111, hlm.1. 
Dan di antara tanda-tanda kekuasaan- Nya ialah Dia menciptakan untukmu isteri-isteri dari jenis mu sendiri, supaya kamu cenderung dan merasa tenteram kepadanya, dan dijadikan- Nya diantaramu rasa kasih dan sayang. Sesungguhnya pada yang demikian itu benar-benar terdapat tanda-tanda bagi kaum yang berfikir.

Menurut mubasyarah, untuk membentuk suatu keluarga yang sakinah mawaddah wa rahmah, diperlukan persiapan-persiapan dengan matang diantaranya adalah pasangan yang akan membentuk keluarga tersebut, harus sudah dewasa, baik secara biologis maupun pedagogis atau bertanggung jawab. Bagi pria harus sudah siap untuk memikul tanggung jawab sebagai kepala keluarga, sehingga berkewajiban memberi nafkah kepada anggota keluarga. Bagi seorang wanita ia harus sudah siap menjadi ibu rumah tangga yang bertugas mengendalikan rumah tangga, melahirkan, mendidik, dan mengasuh anak-anak. ${ }^{9}$

Persoalan kedewasaan merupakan masalah yang sangat penting, khususnya dalam lembaga perkawinan, karena akan membawa pengaruh terhadap keberhasilan dalam membentuk rumah tangga. Orang yang telah dewasa secara fisik dan mental, belum tentu dapat membina dan mendirikan rumah tangga yang sempurna apalagi orang muda dan belum dewasa. Tanpa sikap kedewasaan, problem yang muncul dalam rumah tangga akan disikapi dengan emosional. ${ }^{10}$ Oleh karena itu, kunci sukses dalam perkawinan, menuntut adanya kedewasaan dan kematangan dari segi fisik, mental dan emosional, calon suami dan istri yang akan melangsungkan pernikahan. Usia

9 Mubasyaroh, "Analisis Faktor Penyebab Pernikahan Dini dan Dampaknya Bagi Pelakunya" dalam jurnal YUDISLA, Vol. 7, No. 2, Desember 2016, hal. 395

10 Dewi Iriani, “Analisa Terhadap Batasan Minimal Usia Pernikahan dalam Undangundang Nomor 1 Tahun 1974” dalam Jurnal Justitia Islamica, Vol. 12/Nomor 1 Januari-Juni 2015 
perkawinan yang dilakukan secara matang maka dapat menghasilkan keturunan yang baik dan juga sehat, sehingga akan tercipta suatu perkawinan yang bahagia tanpa harus berakhir dengan sebuah perceraian karena disebabkan ketidakstabilan dan ketidakmatangan emosional dan fisik kedua belah pihak yaitu pasangan suami-istri. ${ }^{11}$

Undang-undang No. 1 Tahun 1974, secara implisit menyebutkan bahwa kedewasaan seseorang sebagai syarat mutlak dalam perkawinan harus ditunjukan dengan usia 19 tahun bagi laki-laki dan 16 tahun bagi perempuan. Pada tahun 2019, undang-undang tersebut telah direvisi menjadi undang-undang no. 16 tahun 2019, dengan ketentuan bahwa usia laki-laki dan perempuan sebagai calon pasangan suamiistri harus 19 tahun. Meskipun sebenarnya, penentuan usia pernikahan sebagai indicator kedewasaan seseorang di beberapa Negara tidaklah sama. Sebagaimana dalam ajaran Islam, tidak ada batasan pasti dalam menentukan usia pernikahan. Sifat kedewasaan inilah, sejatinya yang menjadi patokan seseorang boleh atau tidak dalam melangsungkan pernikahan.

Oleh karenanya, lanjutan ketentuan batas usia pernikahan dalam undang-undang tersebut, dijelaskan bahwa jika terdapat penyimpangan tentang ketentuan batas usia pernikahan, maka dapat meminta dispensasi pernikahan kepada Pengadilan Agama. Dengan demikian, sebenarnya dispensasi diperlukan sebagai tiket yang diberikan hakim kepada calon mempelai dibawah umur untuk melangsungkan pernikahan. Dispensasi pada dasarnya merupakan pelunakan rintangan yang melarang atau membatalkan sebuah pernikahan dalam sebuah kasus khusus atau kelonggaran yang diberikan oleh Pengadilan Agama kepada calon mempelai yang belum cukup untuk

11 Netty Hartati, Islam dan Psikologi, (Jakarta: PT. Raja Grafindo Persada, Edisi 1, 2004), cet. I, hal. 90 
melangsungkan perkawinan atau perkawinan yang seharusnya tidak boleh dilakukan akan tetapi karena adanya alasan tertentu atau sebab tertentu terpaksa diberi dispensasi oleh Pengadilan Agama. ${ }^{12}$

Penetapan Putusan No.0253/Pdt.P/2016/PA.Pbg, menarik untuk dikaji, karena didalamnya menjelaskan tentang argument-argumen dan pertimbangan hakim dalam mengabulkan permohonan pemohon tentang dispensasi pernikahan. Karena dispensasi akan diberikan oleh hakim, jika dalam permohonan tersebut disertai dengan alasanalasan yang mendesak, yaitu suatu keadaan di mana tidak ada pilihan lain dan sangat terpaksa yang mengharuskan utuk dilangsungkannya perkawinan. Alasan mendesak tersebut tidak hanya sekadar klaim, tapi harus ada buktibukti pendukung yang cukup. Oleh karena itu, dalam pemberian dispensasi tersebut, hakim dituntut untuk memberikan pertimbangan yang mengedepankan konsep maslahahat, yaitu pertimbangan kebaikan dan menolak kerusakan (madharat) dalam masyarakat.

Kajian tentang dispensasi pernikahan sebenarnya sudah banyak dilakukan oleh beberapa peneliti, secara umum, kajian tersebut dapat dikelompokkan menjadi tiga, yaitu 1) faktor-faktor yang mempengaruhi melonjaknya kasus dispensasi, seperti Syahruddin Nawi1, \& Salle,13 2) pertimbangan-pertimbangan yang diambil oleh hakim dalam merumuskan putusan, seperti Sri Ahyani,14 3)

12 Nurhidayah, “ Efektivitas Pemberian Dispensasi Perkawinan Terhadap Perkawinan Di Bawah Umur Di Makassar”, dalam jurnal ElIqtishady, Volume 1, Nomor 1, Juni 2019, hlm. 49- 50

13 Syahruddin Nawi1, \& Salle, "Analisis Pengaruh Berbagai Variabel Terhadap Permohonan Dispensasi Pernikahan” dalam Journal of Philosophy (JLP) Volume 1, Nomor 1, Juni 2020

14 Sri Ahyani, "Pertimbangan Pengadilan Agama Atas Dispensasi Pernikahan Usia Dini Akibat Kehamilan Di Luar Nikah", dalam Jurnal Wawasan Hukum, Vol. 34, No. 1, Februari 2016 
regulasi dispensasi dalam upaya penguatan batas usia pernikahan, seperti Mughniatul Ilma. ${ }^{15}$

\section{METODE}

Penelitian ini merupakan model penelitian hukum normative (doctrinal), dengan jenis penelitian library research (kepustakaan) dan menggunakan pendekatan kualitatif. Sumber data primer diperoleh dari salinan ketetapan putusan pengadilan nomor 0253/Pdt.P/2016/PA.Pbg, sedangkan sumber data sekunder berupa buku, artikel jurnal yang berkaitan dengan tema pembahasan. Data yang diperoleh dianalisis dengan menggunakan teknik deskripstif analisis, dimana data-data tersebut didiskripsikan kemudian dianalisis dengan menggunakan teori Miles and Hubermen, yaitu reduksi data, penyajian data dan penarikan kesimpulan.

\section{PEMBAHASAN}

\section{A. Penentuan Batas Usia Pernikahan}

Di Negara Indonesia, perkawinan diatur dalam undang-undang No. 1 Tahun 1974. Dalam undang-undang tersebut pernikahan adalah ikatan lahir batin antara seorang pria dengan seorang wanita sebagai seorang suami istri dengan tujuan membentuk keluarga yang bahagia dan kekal berdasarkan Ketuhanan Yang Maha Esa. Untuk mencapai keluarga yang bahagia dan kekal tersebut, maka pernikahan harus berdasarkan pada aspek kematangan psikologi. Oleh karena, undang-undang tersebut secara spesifik juga mengatur usia pernikahan, sebagai tolok ukur dalam menentukan apakah calon mempelai tersebut sudah siap secara mental atau psikologisnya.

15 Mughniatul Ilma, "Regulasi Dispensasi Dalam Penguatan Aturan Batas Usia Kawin Bagi Anak Pasca Lahirnya Uu No. 16 Tahun 2019” dalam jurnal Al-Manhaj, Vol. 2, No. 2 Juli - Desember 2020: 133-166 
Adapun batas usia pernikahan dalam UndangUndang Perkawinan bab II Pasal 7 ayat 1 disebutkan bahwa pernikahan hanya diijinkan jika pihak pria mencapai umur 19 tahun dan pihak perempuan sudah mencapai umur 16 tahun. Undang-undang tersebut direvisi oleh No 16 tahun 2019, tentang perubahan undang-undang No. 1 Tahun 1974 Tentang Perkawinan. Di mana perubahan tersebut terdapat pada pasal 7 ayat (1) Undang-Undang nomor 16 tahun 2019, yang menyatakan bahwa "Perkawinan hanya dapat diizinkan apabila pria dan wanita sudah mencapai umur 19 (sembilan belas) tahun". 16 Tentunya kebijakan pemerintah dalam menetapkan batasan usia minimal pernikahan ini tentunya sudah melalui proses dan berbagai pertimbangan. Hal ini dimaksudkan agar kedua belah pihak benar-benar siap dan matang dari aspek fisik, psikis, dan mental.

Lebih lanjut Pasal 7 ayat (2) Undang Undang No. 16 Tahun 2019 tentang Perubahan Undang-Undang nomor 1 tahun 1974 menegaskan bahwa dalam hal penyimpangan terhadap ayat (1) pasal ini dapat dimintakan dispensasi kepada Pengadilan atau pejabat lain yang ditunjuk oleh kedua orang tua pihak pria maupun pihak wanita, dengan alasan sangat mendesak disertai bukti-bukti pendukung yang cukup. Lebih lanjut ayat (3) menjelaskan bahwa pemberian dispensasi yang dilakukan oleh Pengadilan, harus mendengarkan pendapat kedua belah calon mempelai yang akan melangsungkan perkawinan. ${ }^{17}$

Dispensasi kawin merupakan perkawinan yang terjadi pada pasangan atau salah satu calon yang ingin menikah pada usia di bawah standar batas usia nikah yang

16 Salinan SK No. No 006265 A, Undang-Undang Republik Indonesia Nomor 16 Tahun 2019 Tentang Perubahan Atas Undang-Undang Nomor 1 Tahun 1974 Tentang Perkawinan.

17 Salinan SK No. No 006265 A, Undang-Undang Republik Indonesia Nomor 16 Tahun 2019 Tentang Perubahan Atas Undang-Undang Nomor 1 Tahun 1974 Tentang Perkawinan. 
sudah ditetapkan oleh Undang-Undang No. 16 Tahun 2019 tentang perubahan undang-undang No. 1 Tahun 1974 tentang perkawinan. Dimana bagi seorang pria dan seorang wanita yang belum mencapai batasan usia tersebut, tetap dapat atau diperbolehkan untuk melangsungkan perkawinan, selain atas izin dari kedua orang tua, juga dengan minta dispensasi kepada Pengadilan atau pejabat lain yang diminta oleh kedua orang tua pihak pria atau pihak wanita. Pembatasan umur pria dan wanita untuk menikah merupakan sebuah langkah kongkrit untuk mencegah terjadinya perkawinan usia dini.

Batasan usia perkawinan diperlukan untuk menentukan apakah perkawinan tersebut merupakan perkawinan di bawah umur ataukah bukan. Batasan usia sebagai salah satu instrumen penilaian yang dinyatakan secara kuantitatif akan memberikan kepastian hukum bagi para pihak yang berkepentingan. Majelis Ulama Indonesia (MUI) mendefinisikan perkawinan di bawah umur adalah perkawinan yang dilaksanakan sesuai dengan syarat dan rukunnya, namun salah satu dari kedua mempelainya atau terkadang kedua mempelainya belum baligh dan secara psikis belum siap menjalankan tanggungjawab kerumahtanggaan.

Menurut MUI yang dijadikan batasan adalah baligh, sementara itu kriteria baligh sifatnya kualitatif dan sangat relatif bagi setiap orang.

Mengenai usia perkawinan pada dasarnya Hukum Islam tidak mengatur secara mutlak tentang batas umur perkawinan. Tidak adanya ketentuan agama tentang batas umur minimal dan maksimal untuk melangsungkan perkawinan, diasumsikan memberi kelonggaran bagi manusia untuk mengaturnya. Al-Qur'an mengisyaratkan bahwa orang yang akan melangsungkan perkawinan 
haruslah orang yang siap dan mampu. Sebagaimana firman Allah SWT dalam QS. An-Nur ayat 32 :

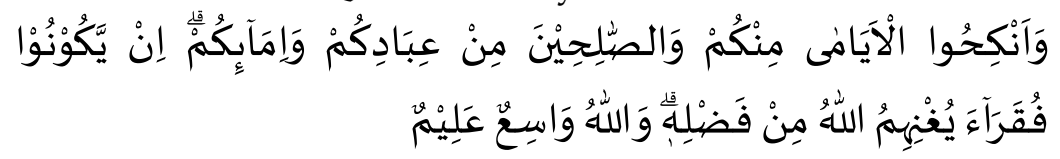

Dan kawinkanlah orang-orang yang sendirian di antara kamu dan orang-orang yang layak (berkawin) dari hambahamba sahayamu yang laki-laki dan hamba-hamba sahayamu yang perempuan. Jika mereka miskin, Allah akan memampukan mereka dengan karunia-Nya. Dan Allah Maha Luas (pemberian-Nya) lagi Maha Mengetahui.

Kata shalihin dalam ayat diatas dipahami oleh banyak ulama dalam arti "yang layak kawin" artinya yang mampu secara mental dan spiritual untuk membina rumah tangga. Begitu pula dengan hadits Rasulullah SAW, yang menganjurkan kepada para pemuda untuk melangsungkan perkawinan dengan syarat adanya kemampuan.:

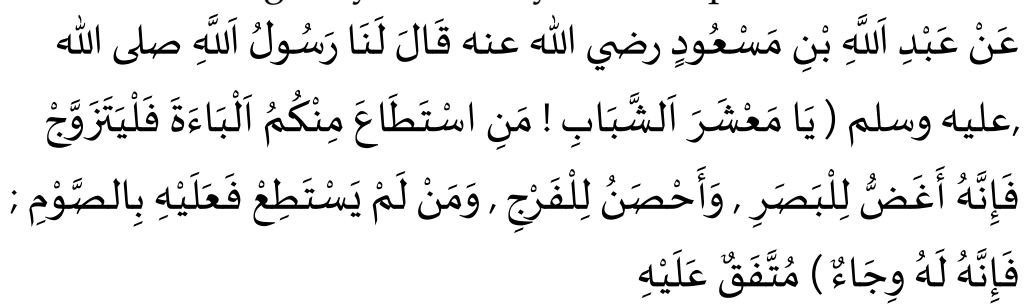

"Abdullah Ibnu Mas'ud Radliyallaahu 'anhu berkata: Rasulullah Shallallaahu 'alaihi wa sallam bersabda pada kami: "Wahai generasi muda, barangsiapa di antara kamu telah mampu berkeluarga hendaknya ia kawin, karena ia dapat menundukkan pandangan dan memelihara kemaluan. Barangsiapa belum mampu hendaknya berpuasa, sebab ia dapat mengendalikanmu." (Muttafaq Alaihi).

Dari uraian diatas, dapat disimpulkan bahwa secara tidak langsung, al-Qur'an dan Hadits mengakui bahwa kedewasaan sangat penting dalam perkawinan. Usia dewasa 
dalam figh ditentukan dengan tanda-tanda yang bersifat jasmani yaitu tanda-tanda baligh secara umum antara lain, sempurnanya umur 15 (lima belas) tahun bagi pria dan perempuan, ihtilam bagi pria dan perempuan serta haid pada perempuan minimal pada umur 9 (sembilan) tahun. ${ }^{18}$ Dengan terpenuhinya kriteria baligh maka telah memungkinkan seseorang melangsungkan perkawinan. ${ }^{19}$ Sehingga kedewasaan seseorang dalam Islam sering diidentikkan dengan baligh. ${ }^{20}$

Pernyataan diatas sesuai dengan pendapat Ibn Syubrumah, di mana beliau menyatakan bahwa anak laki-laki ataupun anak perempuan di bawah umur tidak dianjurkan untuk dikawinkan. Mereka hanya boleh dikawinkan setelah mencapai usia baligh dan melalui persetujuan yang berkepentingan secara eksplisit. ${ }^{21}$

\section{B. Deskripsi Putusan No.0253/Pdt.P/2016/PA.Pbg Tentang Dispensasi Pernikahan}

Pokok putusan No.0253/Pdt.P/2016/PA.Pbg ini menjelaskan tentang permohonan dispensasi pernikahan untuk anak pemohon. Pemohon adalah seorang perempuan yang berusia 48 tahun, beragama Islam, pekerjaan pedagang, bertempat tinggal di RT 007, RW 003 Desa Kejobong, Kecamatan Kejobong, Kabupaten Purbalingga. Pemohon telah mengajukan surat pada tanggal 25 Juli 2019 ke

${ }^{18}$ Salim bin Samir al Hadhramy, tt, Safinah an Najah, (Dar al -Abidin, Surabaya, h. 15- 16

${ }_{19}$ Amir Syarifuddin, 2008, Ushul Fiqh, Jilid I, Cet. III, Prenada Media, Jakarta, h. 394

20 Baligh adalah cukup umur. Lihat Departemen Pendidikan Nasional, 2005, Kamus Besar Babasa Indonesia, Edisi III, Balai Pustaka, Jakarta, Cet. III, h. 96

21 Husain Muslim bin Hajjaj, tt, Shabih Muslim, Juz I, (Bandung: Dahlan, t.t.) h. 100 
Kepaniteraan Perkara Pengadilan Agama Purbalingga, dan tercatat dengan Nomor : 0253/Pdt.P/2016/PA.Pbg. ${ }^{22}$

Dalam surat permohonan tersebut, pemohon telah mengemukakan bahwa anak pemohon (calon pasangan perempuan) yang lahir pada tanggal 18 Juni 1998 (18 tahun) akan melangsungkan pernikahannya dengan calon pasangan suami yang lahir pada tanggal 26 November 1998 (18 tahun). Berdasarkan ketentuan hukum Islam maupun undang-undang yang berlaku, syarat-syarat untuk melangsungkan pernikahan bagi kedua calon pasangan semua telah terpenuhi, kecuali syarat usia. Berdasarkan surat penolakan dari Kantor Urusan Agama (KUA) Kecamatan Kejobong Kabupaten Purbalingga dengan nomor registrasi: 0232/ Kua.11.03.13/ PW.01/ 11/ 2016 tertanggal 21 November 2018, usia kedua calon mempelai baru 18.23 Padahal syarat mutlak untuk diperbolehkannya pernikahan, usia kedua calon mempelai harus mencapai minimal 19 tahun. ${ }^{24}$

Pemohon juga menjelaskan bahwa keluarga calon mempelai laki-laki telah melamar anak pemohon, dan kelaurga kedua belah pihak telah merestui hubungan kedua calon mempelai. Keluarga kedua calon mempelai tersebut telah sepakat untuk segera menikahkannya, karena adanya alasan yang sangat mendesak. Alasan mendesak yang dijadikan sebagai alasan permohonan dispensasi pernikahan adalah hubungan kedua calon mempelai yang sudah

22 Salinan putusan perkara Nomor : 0253/Pdt.P/2016/PA.Pbg

${ }^{23}$ Salinan putusan perkara Nomor : 0253/Pdt.P/2016/PA.Pbg

${ }^{24}$ Undang-Undang No. 16 tahun 2019 tentang Perubahan Undangundang No. 1 tahun 1974 tentang perkawinan. 
sedemikian eratnya, bahkan keduanya telah melakukan hubungan badan layaknya suami istri yang sah, sehingga menyebabkan calon mempelai perempuan (anak pemohon) hamil kurang lebih 3 minggu. Dengan kondisi seperti itu, pemohon sangat khawatir jika kedua calon mempelai tersebut tidak segera dinikahkan akan menimbulkan mudhorot yang lebih banyak lagi. ${ }^{25}$

Di samping itu, calon mempelai laki-laki yang berstatus jejaka telah akil baligh dan sudah siap untuk menjadi seorang suami dan atau kepala rumah tangga. Dengan pekerjaan yang ditekuninya selama ini, yaitu sebagai montir dibengkel motor telah memperoleh penghasilan Rp. 1.350.000,- (satu juta tiga ratus lima puluh ribu rupiah) per bulan. Begitupun calon mempelai perempuan, sudah siap pula untuk menjadi seorang isteri dan atau ibu rumah tangga bagi anak-anak mereka kelak. ${ }^{26}$

Berdasarkan uraian-uraian diatas, Pemohon memohon kepada Majelis Hakim untuk memeriksa dan memutus perkara tersebut dan menjatuhkan putusan sebagai berikut: 1) mengabulkan permohonan Pemohon; 2) menetapkan, memberikan dispensasi kepada Pemohon untuk menikahkan anak Pemohon dengan calon suaminya bernama; 3) Menetapkan biaya perkara ini dibebankan kepada Pemohon dan Subsidair; 4) Atau menjatuhkan keputusan lain yang seadil-adilnya.

Pada saat sidang ditetapkan, Pemohon datang menghadap sendiri di persidangan dan Majelis Hakim telah berusaha menasehati Pemohon supaya menunda untuk

25 Salinan putusan perkara Nomor : 0253/Pdt.P/2016/PA.Pbg

26 Salinan putusan perkara Nomor : 0253/Pdt.P/2016/PA.Pbg 
menikahkan anaknya sampai memenuhi ketentuan umur 19 tahun, tetapi tidak berhasil. Kemudian, pemeriksaan perkara ini dimulai dengan membacakan surat permohonan yang isinya tetap dipertahankan oleh Pemohon. Setelah pemeriksaan surat permohonan, Majelis Hakim mendengarkan keterangan dari kedua calon mempelai yang poda pokoknya adalah mereka sudah berpacaran sejak 1 tahun yang lalu dan sudah saling mencintai, sulit untuk dipisahkan satu sama lain; mereka sudah siap dan sepakat untuk menikah dan membangun rumah tangga sebagai pasangan suami istri; mereka ingin segera menikah karena sudah hamil disebabkan oleh hubungan kelamin sebagaimana pasangan suami istri. ${ }^{27}$

Untuk menguatkan alasan-alasan sebagaimana yang dijelaskan diatas, Pemohon telah menyerahkan beberapa dokumen, yaitu fotokopi KTP (pemohon, dan kedua calon mempelai), fotokopi Kutipan Akta Nikah Pemohon, fotokopi Kartu Keluarga Pemohon, fotokopi Kutipan Akta Kelahiran kedua calon mempelai, fotokopi Surat Keterangan sehat untuk nikah, Tes Kehamilan dari Dinas Kesehatan Kabupaten Purbalingga, dan fotokopi Surat Penolakan Pernikahan dari Kementerian Agama Kantor Urusan Agama Kecamatan Kejobong Kabupaten Purbalingga. ${ }^{28}$

Di samping beberapa dokumen yang diserahkan ke Mejlis Hakim, Pemohon juga mendatangkan dua orang saksi. Saksi pertama berumur 36 tahun dan saksi kedua berumur 43 tahun. Masing-masing saksi sebelum memberikan kesaksiannya, mereka telah disumpah dibawah

27 Salinan putusan perkara Nomor : 0253/Pdt.P/2016/PA.Pbg

28 Salinan putusan perkara Nomor : 0253/Pdt.P/2016/PA.Pbg 
kitab Suci Al-Qur'an. Dalam kesaksianya, kedua saksi tersebut mengiyakan apa yang telah disampaikan oleh Pemohon. ${ }^{29}$

Dari beberapa penjelasan dan dokumen-dokumen yang dihadirkan oleh Pemohon, maka Majelis Hakim sesuai dengan kapasitasnya sebagai pemangku kebijakan dalam memberikan putusan perkara seadil-adilnya telah menetapkan putusan No.0253/Pdt.P/2016/PA.Pbg. Di mana amar putusan tersebut menyebutkan bahwa: 1) Mengabulkan permohonan Pemohon; 2) Menetapkan, memberikan dispensasi kawin kepada anak Pemohon untuk menikah dengan calon suaminya; dan 3) Membebankan kepada Pemohon untuk membayar biaya perkara tersebut sebesar Rp. Rp. 181.000,- (seratus delapan puluh satu ribu rupiah). ${ }^{30}$

\section{Pertimbangan Hakim dalam Penetapan Putusan No.0253/Pdt.P/2016/PA.Pbg Tentang Dispensasi Pernikahan}

Hakim sebagai pelaksana kehakiman memiliki kemerdekaan dan otoritas dalam menjalankan tugasnya. Kemerdekaan hakim dalam menjalankan tugasnya ia tidak dipengaruhi oleh suatu instansi manapun karena hakim hanya tunduk kepada hukum dan keadilan. Di samping itu, dalam membuat putusan hakim dituntut harus mempertimbangkan semua aspek temuan yang ditemukan didalam persidangan dan semua temuan tersebut harus dipertimbangkan untuk selanjutnya dijadikan pertimbangan untuk menentukan hukum.

Pertimbangan hakim dalam suatu penetapan putusan perkara memiliki posisi sangat penting, melihat

\footnotetext{
${ }^{29}$ Salinan putusan perkara Nomor : 0253/Pdt.P/2016/PA.Pbg

30 Salinan putusan perkara Nomor : 0253/Pdt.P/2016/PA.Pbg
} 
valid tidaknya suatu putusan berdasarkan pertimbangan tersebut. Oleh karenanya, pertimbangan hakim merupakan salah satu aspek terpenting dalam menentukan terwujudnya nilai dari suatu putusan perkara yang mengandung keadilan (ex aequo et bono), kepastian hukum, dan mengandung kebermanfaatan bagi para pihak yang bersangkutan sehingga pertimbangan hakim ini harus disikapi dengan teliti, baik, dan cermat. Jika pertimbangan hakim tidak teliti, baik, dan cermat, maka putusan perkara yang berasal dari pertimbangan hakim tersebut akan dibatalkan oleh Pengadilan Tinggi/Mahkamah Agung. ${ }^{31}$

Secara umum pertimbangan hakim dapat dikelompokan menjadi dua, yaitu pertimbangan hukum dan pertimbangan keadilan masyarakat. Masing-masing dari pertimbangan tersebut sesuai dengan konteks putusan No.0253/Pdt.P/2016/PA.Pbg akan diuraikan sebagai berikut:

1. Pertimbangan hukum

a. Bukti surat

Pertimbangan hukum yang berupa bukti surat ini merupakan beberapa dokumen yang diperlukan untuk memperjelas status pemohon dengan orang yang diajukan permohonan. Oleh karenanya, bukti surat yang diajukan dalam kasus diatas adalah sebagai berikut; Fotokopi KTP pemohon, Fotokopi Kutipan Akta Nikah, Fotokopi Kartu Keluarga, Fotokopi Kutipan Akta Kelahiran anak (anak pemohon), Fotokopi KTP anak pemohon, Fotokopi Kutipan Akta Kelahiran (calon mempelai wanita), Surat Keterangan Domisili, Fotokopi Surat Keterangan sehat untuk kawin (calon mempelai wanita), Tes Kehamilan dari Dinas Kesehatan

31 Mukti Arto, Praktek Perkara Perdata pada Pengadilan Agama, cet V (Yogyakarta, Pustaka Pelajar, 2004), h.140

Tasyri': Journal of Islamic Law, 
Kabupaten Purbalingga, dan Fotokopi Surat Penolakan Pernikahan dari Kementerian Agama Kantor Urusan Agama Kecamatan Kejobong Kabupaten Purbalingga.

b. Bukti saksi

Adapun pertimbangan hukum berupa bukti saksi yang biasa dihadirkan oleh hakim dalam persidangan adalah dua orang. Meskipun sebenarnya saksi hanya kalau diperlukan saja. Dalam kasus diatas, hakim menghadirkan kedua saksi untuk memperkuat pertimbangannya dalam menentukan putusan perkaranya. Kedua saksi tersebut, masing-masing bertempat tinggal yang berbeda. Saksi I merupakan perangkat desa Nangkod Kec. Kejobong Kab. Purbalingga dan Saksi II bertempat tinggal di desa Kejobong Kec. Kejobong Kab. Purbalingga. 32

2. Pertimbangan keadilan masyarakat

Pertimbangan keadilan masyarakat diperlukan untuk mendapatkan hukum atau putusan perkara yang berorientasi pada keadilan. Karena bagaimana pun pengadilan adalah tempat dimana keadilan yang dicita-citakan oleh masyarakat dapat diperoleh bagi siapapun yang mencarinya. Oleh karena itu, pertimbangan keadilan harus diperhatikan dengan serius oleh hakim. Namun demikian, keadilan yang dimaksudkan bukanlah keadilan yang semu, melainkan keadilan yang nyata yang dapat diperoleh dan dirasakan bagi yang bersangkutan juga masyarakat sekitarnya.

Dalam konteks kasus diatas, seringkali pernikahan dianggap sebagai solusi alternatif bagi penyelesaian masalah sosial yang akan terjadi, yaitu menikahkan

32 Salinan putusan perkara Nomor : 0253/Pdt.P/2016/PA.Pbg 
anak yang sudah hamil terlebih dahulu untuk menutup malu. Hal ini berdasarkan stigma buruk yang disandang bagi anak yang hamil diluar nikah di tengah-tengah masyarakat, yaitu perempuan yang hamil tanpa suami akan dihina dan dikucilkan oleh masyarakat. Ini bisa mengakibatkan perempuan tersebut tidak mau bergaul dan mementingkan diri sendiri (menutup diri). Hal ini juga bisa terjadi pada anak yang akan dilahirkannya. 33

Selain kedua pertimbangan di atas, jika diperhatikan secara seksama atas salinan penetapan putusan perkara No.0253/Pdt.P/2016/PA.Pbg, maka yang menjadi pertimbangan hakim adalah aspek kemaslahatan. Kemaslahatan merupakan aspek terpenting dalam setiap penetapan hukum, sebab tanpa memperhatikan aspek kemaslahatan tersebut, maka sejatinya hakim telah menetapkan hukum yang mandul. Dikatakan sebagai hukum yang mandul karena putusan hakim tidak mengenai sasaran, sehingga maksud diturunkannya (diputuskannya) hukum hukum tersebut tidak berimplikasi pada pembenahan dan perbaikan umat.

Kemaslahatan sebagai inti dari diturunkannya (ditetapkannya) sebuah hukum sejatinya ada dua aspek penting dalam mencapai kemaslahatan tersebut. Yaitu dengan cara melaksanakan tuntutan sebuah hukum tersebut atau dengan cara menghindar dari sesuatu yang membahayakannya (jalb al-mashalih dan dar'ul mafasid). ${ }^{34}$

Dalam konteks penetapan putusan kasus diatas, hakim juga berdasarkan pada kemaslahatan yaitu menolak bahaya didahulukan atas mendatangkan kebaikan dan Kemadharatan harus dihilangkan yang pada dasarnya setiap insan tidak diizinkan mengadakan suatu kemadharatan,

33 Salinan putusan perkara Nomor : 0253/Pdt.P/2016/PA.Pbg

34 Salinan putusan perkara Nomor : 0253/Pdt.P/2016/PA.Pbg 
baik berat maupun ringan terhadap dirinya atau terhadap orang lain. Pada prinsipnya kemadharatan harus dihilangkan, tetapi dalam menghilangkan kemadharatan itu tidak boleh sampai menimbulkan kemadharatan lain baik ringan apalagi lebih berat. Namun, bila kemadharatan itu tidak dapat dihilangkan kecuali dengan menimbulkan kemadharatan yang lain maka haruslah memilih kemadharatan yang relatif lebih ringan dari yang telah terjadi. Menurut persepsi hakim, madharatnya adalah ditakutkan bila tidak dinikahkan akan menambah dosa dan terjadi perkawinan di bawah tangan yang akan mengacaukan proses-proses hukum yang akan terjadi berikutnya atau mengacaukan hakhak hukum anak yang dilahirkannya menurut undang-undang.

Pertimbangan-pertimbangan lain yang harus diperhatikan oleh hakim selain yang dijelaskan diatas adalah antara undang-undang yang ada dengan fakta dalam persidangan. Dalam perkara dispensasi pernikahan peraturan yang mengatur batasan usia seseorang yang dibolehkan melakukan pernikahan adalah Pasal 7 UndangUndang Nomor 1 Tahun 1974, yang kemudian diubah menjadi Undang-undang Nomor 16 tahun 2019 tentang perubahan Undang-Undang Nomor 1 Tahun 1974 Tentang Perkawinan, yang menyebutkan bahwa bila seseorang (yang beragama Islam) belum mencapai usia minimum, dapat mengajukan dispensasi nikah kepada pengadilan agama. Aturan lain yang mengatur dispensasi nikah adalah pasal 15 Kompilasi Hukum Islam, yang maksudnya sama dengan Undang-Undang Nomor 1 Tahun 1974, namun demikian aturan hukum tersebut tidak merinci alasannya.

Dari uraian tersebut diatas dapat ditarik kesimpulan bahwa Hakim dalam menetapkan putusan perkara No.0253/Pdt.P/2016/PA.Pbg tentang pemberian dispensasi pernikahan terhadap pemohon mempunyai beberapa 
pertimbangan. Pertama berdasarkan pada peraturan yang ada yang mana dalam pertimbangan hakim dalam menjatuhkan penetapannya itu harus disesuaikan dengan hukum yang ada. Kedua, berdasarkan keterangan dari bukti- bukti dan keterangan dari saksi-saksi kemudian dari keterangan saksi-saksi tersebut dicocokkan dengan keterangan dari pemohon, saksi yang dihadirkan oleh hakim dalam persidangan adalah dua orang. Ketiga, berdasarkan kemaslahatan yang hakiki. Artinya adalah kemaslahatan yang memang real terjadi dan harus diperjuangkan.

Kemaslahatan tersebut berupa penolakan mudlorat yang jauh lebih besar yaitu terjadinya kemaksiatan atau perbuatan zina yang terulang ulang. Karena keduanya sudah seperti pasangan suami istri tanpa ada batas apapun, sehingga jika tidak dinikahkan kedua calon mempelai akan melakukan perbuatan zina berulang kali.

Meskipun diakui bahwa, dengan diizinkannya pernikahan antara kedua calon mempelai, tentunya juga mengandung risiko yang akan dialami baik oleh kedua calon mempelai, keluarga maupun anaknya kelak. Namun kekhawatiran-kekhawatiran tersebut masih bersifat semu, sehingga belum benar terjadi.

\section{PENUTUP}

Dispensasi pernikahan merupakan suatu keringan terkait dengan usia pernikahan. Di mana undang-undang No 16 tahun 2019 tentang perubahan undang-undang No. 1 tahun 1974 tentang perkawinan, menyatakan bahwa batas usia pernikahan bagi laki-laki dan perempuan adalah 19 tahun. Oleh karenanya, perihal salah satu atau keduaduanya calon pasangan mempelai jika belum mencapai usia 19 tahun maka dapat dimohonkan dispensasi dari Pengadilan Agama yang disertai dengan alasan yang mendesak, yaitu suatu keadaan di mana tidak ada pilihan lain dan sangat terpaksa yang mengharuskan utuk 
dilangsungkannya perkawinan. Alasan mendesak tersebut tidak hanya sekadar klaim, tapi harus ada bukti-bukti pendukung yang cukup. Dalam memberikan dispensasi tersebut, hakim dituntut untuk memberikan pertimbangan yang mengedepankan konsep maslahahat, yaitu pertimbangan kebaikan dan menolak kerusakan (madharat) dalam masyarakat.

Penetapan putusan No.0253/Pdt.P/2016/PA.Pbg tentang dispensasi pernikahan setidaknya telah mempertimbangkan 3 aspek sehingga permohonan tentang dispensasi tersebut dikabulkan. Pertama, berdasarkan pada peraturan yang ada yang mana dalam pertimbangan hakim dalam menjatuhkan penetapannya itu harus disesuaikan dengan hukum yang ada. Kedua, berdasarkan keterangan dari bukti- bukti dan keterangan dari saksi-saksi kemudian dari keterangan saksi-saksi tersebut dicocokkan dengan keterangan dari pemohon, saksi yang dihadirkan oleh hakim dalam persidangan adalah dua orang. Ketiga, berdasarkan kemaslahatan yang hakiki. Artinya adalah kemaslahatan yang memang real terjadi dan harus diperjuangkan.

\section{DAFTAR PUSTAKA}

Al Mashri, Syekh Mahmud. Perkawinan Idaman. Jakarta: Qisthi Press, 2015, cet. 111.

Amir Syarifuddin, Ushul Figh, Jilid I, Cet. III. Jakarta: Prenada Media, 2008.

Arto, Mukti. Praktek Perkara Perdata pada Pengadilan Agama. Yogyakarta: Pustaka Pelajar, 2004

Departemen Pendidikan Nasional, Kamus Besar Bahasa Indonesia, Edisi III, Balai Pustaka, Jakarta, Cet. III. 2005,

Husain Muslim bin Hajjaj, Shahih Muslim, Juz I. Bandung: Dahlan, t.t. 
Iriani, Dewi. "Analisa Terhadap Batasan Minimal Usia Pernikahan dalam Undangundang Nomor 1 Tahun 1974" dalam Jurnal Justitia Islamica, Vol. 12/Nomor 1 Januari-Juni 2015

Mubasyaroh, "Analisis Faktor Penyebab Pernikahan Dini dan Dampaknya Bagi Pelakunya" dalam jurnal YUDISIA, Vol. 7, No. 2, Desember 2016.

Mughniatul Ilma, "Regulasi Dispensasi Dalam Penguatan Aturan Batas Usia Kawin Bagi Anak Pasca Lahirnya Uu No. 16 Tahun 2019" dalam jurnal Al-Manhaj, Vol. 2, No. 2 Juli - Desember 2020: 133-166

Nastution, Andi Hakim. Membina keluarga bahagia. Jakarta: PT Pustaka Antara, 1996, cet. 4.

Netty Hartati, Islam dan Psikologi, Jakarta: PT. Raja Grafindo Persada, Edisi 1, 2004, cet. I.

Nurhidayah, " Efektivitas Pemberian Dispensasi Perkawinan Terhadap Perkawinan Di Bawah Umur Di Makassar", dalam jurnal El-Iqtishady, Volume 1, Nomor 1, Juni 2019.

Salim bin Samir al Hadhramy, Safinah an Najah. Dar al Abidin, Surabaya, $\mathrm{tt}$,

Salinan putusan perkara Nomor : 0253/Pdt.P/2016/PA.Pbg Salinan SK No. No 006265 A, Undang-Undang Republik Indonesia Nomor 16 Tahun 2019 Tentang Perubahan Atas Undang-Undang Nomor 1 Tahun 1974 Tentang Perkawinan.

Sri Ahyani, "Pertimbangan Pengadilan Agama Atas Dispensasi Pernikahan Usia Dini Akibat Kehamilan Di Luar Nikah", dalam Jurnal Wawasan Hukum, Vol. 34, No. 1, Februari 2016

Syahrani, Ridwan, Seluk Beluk dan Asas-asas Hukum Perdata, Bandung: Pustaka Setia, 2015.

Syahruddin Nawi1, \& Salle, "Analisis Pengaruh Berbagai Variabel Terhadap Permohonan Dispensasi 
Pernikahan" dalam Journal of Philosophy (JLP) Volume 1, Nomor 1, Juni 2020

Syarifudin, Amir. Hukum Perkawinan Islam diIndonesia. Jakarta: Kencana, 2006.

Undang-Undang No. 16 tahun 2019 tentang Perubahan Undang-undang No. 1 tahun 1974 tentang perkawinan.

Undang-undang Nomor 1 Tahun 1974 tentang Perkawinan. 